\title{
Time to move the fat
}

\author{
Benjamin P. Weaver, Aileen K. Sewell, and Min Han \\ Howard Hughes Medical Institute, Department of Molecular, Cellular, and Developmental Biology, University of Colorado, \\ Boulder, Colorado 80309, USA
}

In this issue of Genes et Development, Dowen and colleagues (pp. 1515-1528) elegantly unify two previously unconnected aspects of physiology. The investigators provide significant genetic evidence to support a critical link between developmental timing decisions and the regulation of lipid mobilization at the transition to adulthood in Caenorhabditis elegans. This novel connection involves cross-tissue signaling from the hypodermis (epidermis) to the intestine to promote reproductive success in the germline.

Regulation of animal development involves more than cell division, fate specification, differentiation, and pattern formation; it also requires changes in metabolic status. Metabolism (status and biomolecule availability) not only profoundly impacts various developmental events but also is affected in turn by key developmental decisions to support various cellular functions. For example, the unique ability of a specific cell type to store and consume energy is the consequence of particular developmental events. The interplay of development and metabolism has been a relatively underexplored research area partly due to the immense complexity of the underlying mechanisms not only within cells but also between tissues. For example, the overall production and consumption of certain biomaterials, such as lipids, must somehow be coordinated with temporal developmental stages. However, the temporal developmental regulation could be initiated in a tissue separate from the site of the major fat metabolic events. The study of such crosstalk, requiring the use of genetic model organisms, is highly desirable.

Fat storage and mobilization have an intimate relationship with animal reproductive development, as the lipids provide needed resources during oogenesis and early embryogenesis (Fig. 1; Della Torre et al. 2014). Lipid storage has long been considered to be a reproductive adaption and may serve as the connection between development of somatic tissues and the germline. Mobilization of fat from somatic tissues to germ cells is a critical step in

[Keywords: vitellogenesis; fat metabolism; microRNAs; insulin; mTORC2; pqm-1]

Corresponding author: benjaminpweaver@gmail.com

Article is online at http://www.genesdev.org/cgi/doi/10.1101/gad.285460.

116. this interaction and must be carefully coordinated with overall development. In the nematode Caenorhabditis elegans, larvae (juveniles) consume food to fuel their own growth and development. By adulthood, lipids accumulate as droplets in the intestinal cells, and the transition to full reproductive capacity includes the mobilization of these lipids (Lemieux and Ashrafi 2015). Mobilization of large fat stores (vitellogenesis) requires assembly of lowdensity protein lipid (LDL) particles with key proteins termed vitellogenins (similar to ApoB genes in humans) (Fig. 1) that are expressed at the onset of adulthood. Vitellogenins shuttle the lipids from somatic tissue to oocytes and embryos to support reproduction. Several other recent studies have revealed diverse roles for and regulation of vitellogenins (Goszczynski et al. 2016; Seah et al. 2016; Wang et al. 2016). Previous work has also indicated a critical regulation of this process by the insulin/IGF-like signaling (IIS) pathway to coordinate nutrient availability and animal growth/development (DePina et al. 2011). Additional regulation, especially the connection with developmental timing that controls the larval-to-adult transition, was unknown.

Developmental timing has been extensively studied in C. elegans, focusing mainly on the heterochronic genetic pathway that controls the temporal transition between different developmental stages (Ambros 2000). MicroRNAs (miRNAs), including the first two miRNAs (LIN4 and LET-7) ever discovered, have been shown to play critical roles in maintaining the precise gene expression dynamics needed for the temporal switch (Ambros 2011). However, much of the timing regulation focuses on activities in hypodermal seam cells that have particular cell division and differentiation patterns to mark the different stages. How the activities of the heterochronic pathway impact development in other tissues, particularly fat metabolism in the intestine, remains largely unknown. Dowen et al. (2016) have made a major advance toward answering this important question.

Dowen et al. (2016) used a powerful tandem genetic screen approach to identify genes impacting the expression of vitellogenin genes in order to uncover the

(C) 2016 Weaver et al. This article is distributed exclusively by Cold Spring Harbor Laboratory Press for the first six months after the full-issue publication date (see http://genesdev.cshlp.org/site/misc/terms.xhtml). After six months, it is available under a Creative Commons License (Attribution-NonCommercial 4.0 International), as described at http:// creativecommons.org/licenses/by-nc/4.0/. 


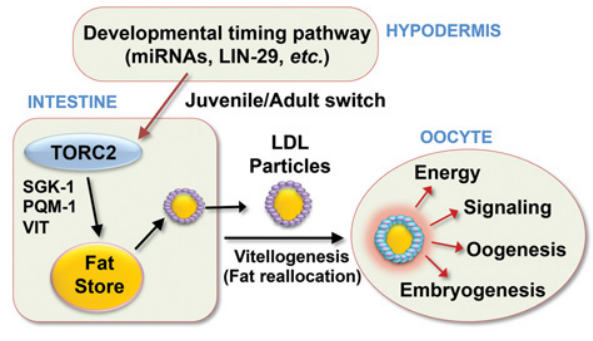

Figure 1. Developmental timing control of fat mobilization. Signaling from the hypodermis (epidermis) initiates fat mobilization from the intestinal reserve. Lipids are transported by LDL-type particles complexed with proteins (VIT) to developing oocytes.

regulatory mechanism of this metabolic switch. The first screen used a transgene reporter and RNAi to identify 16 genes required for expression of a vitellogenin gene (vit3). Identification of miRNA-specific argonautes (alg-1/2) and elt GATA factor genes (elt-1/2) provided strong clues that developmental timing pathways must somehow signal from the hypodermis to the intestine. Less well known in developmental timing, the GATA factor ELT-1 was recently shown to exert developmental timing control by promoting expression of let-7 miRNA (Cohen et al. 2015). Pursuing this possibility, the investigators found that developmental timing regulators, including specific miRNAs LIN-4 and LET-7 and transcription factor LIN29 , promote hypodermal signaling to the intestine to cue a metabolic shift from intestinal lipid storage to germline lipid utilization. The investigators further provide evidence that the hypodermal LIN-29-initiated signal to the intestine is mediated by the TORC2 complex (let363/tor and rict-1/rictor) and not TORC1 (daf-15/raptor). They also demonstrated that SGK-1, a known kinase downstream from TORC2, critically mediates the regulation of vitellogenesis by LIN-29, consistent with previous work showing that TORC2 signaling through SGK-1 regulates C. elegans lipid storage (Jones et al. 2009). The investigators then carried out a genetic suppressor screen to identify genes acting downstream from SGK-1 to regulate vit-3 expression. They identified $p q m-1$ that encodes a $\mathrm{C} 2 \mathrm{H} 2$ zinc finger transcription factor, suggesting that this transcription factor is negatively regulated by SGK-1 and subsequently inhibits the transcription of the vitellogenins.

The finding that the developmental timing regulatory mechanism in the hypodermis potentially regulates lipid mobilization, as suggested by vitellogenin gene expression, provides an exciting insight regarding the regulation of specific developmental decisions on metabolism. Since LIN-29 functions to specify the larval-to-adult transition (Ambros 2000), when the reproductive system will advance to oogenesis, this newly identified role of LIN-29 in mediating the timing of a signal to mobilize lipids makes perfect sense. Moreover, the novel roles revealed for TORC2, SGK-1, and PQM-1 provide valuable mechanistic insights about this signaling event, creating a useful genetic scaffold for future studies. Truly, use of the many genetic tools available in C. elegans has revealed an unexpected, dual-tissue genetic connection. It will be very interesting in future studies to determine the physiological impact of these genetic changes that occur in distinct tissues but act on oocyte maturation, as others have questioned the impact of yolk protein production on reproductive success (Van Rompay et al. 2015). Further analysis at the protein level, coupled with functional assays, will make significant contributions to our understanding.

\section{References}

Ambros V. 2000. Control of developmental timing in Caenorhabditis elegans. Curr Opin Genet Dev 10: 428-433.

Ambros V. 2011. MicroRNAs and developmental timing. Curr Opin Genet Dev 21: 511-517.

Cohen ML, Kim S, Morita K, Kim SH, Han M. 2015. The GATA factor elt-1 regulates $C$. elegans developmental timing by promoting expression of the let-7 family microRNAs. PLoS Genet 11: e1005099.

Della Torre S, Benedusi V, Fontana R, Maggi A. 2014. Energy metabolism and fertility: a balance preserved for female health. Nat Rev Endocrinol 10: 13-23.

DePina AS, Iser WB, Park SS, Maudsley S, Wilson MA, Wolkow CA. 2011. Regulation of Caenorhabditis elegans vitellogenesis by DAF-2/IIS through separable transcriptional and posttranscriptional mechanisms. BMC Physiol 11: 11.

Dowen RH, Breen PC, Tullius T, Conery AL, Ruvkun G. 2016. A microRNA program in the C. elegans hypodermis couples to intestinal mTORC2/PQM-1 signaling to modulate fat transport. Genes Dev (this issue). doi: 10.1101/gad.283895.116.

Goszczynski B, Captan VV, Danielson AM, Lancaster BR, McGhee JD. 2016. A 44 bp intestine-specific hermaphroditespecific enhancer from the $C$. elegans vit-2 vitellogenin gene is directly regulated by ELT-2, MAB-3, FKH-9 and DAF-16 and indirectly regulated by the germline, by daf-2/insulin signaling and by the TGF- $\beta /$ Sma/Mab pathway. Dev Biol 413: $112-127$.

Jones KT, Greer ER, Pearce D, Ashrafi K. 2009. Rictor/TORC2 regulates Caenorhabditis elegans fat storage, body size, and development through sgk-1. PLoS Biol 7: e60.

Lemieux GA, Ashrafi K. 2015. Insights and challenges in using C. elegans for investigation of fat metabolism. Crit Rev Biochem Mol Biol 50: 69-84.

Seah NE, de Magalhaes Filho CD, Petrashen AP, Henderson HR, Laguer J, Gonzalez J, Dillin A, Hansen M, Lapierre LR. 2016. Autophagy-mediated longevity is modulated by lipoprotein biogenesis. Autophagy 12: 261-272.

Van Rompay L, Borghgraef C, Beets I, Caers J, Temmerman L. 2015. New genetic regulators question relevance of abundant yolk protein production in C. elegans. Sci Rep 5: 16381.

Wang H, Jiang X, Wu J, Zhang L, Huang I, Zhang Y, Zou X, Liang B. 2016. Iron overload coordinately promotes ferritin expression and fat accumulation in Caenorhabditis elegans. Genetics 203: 241-253. 


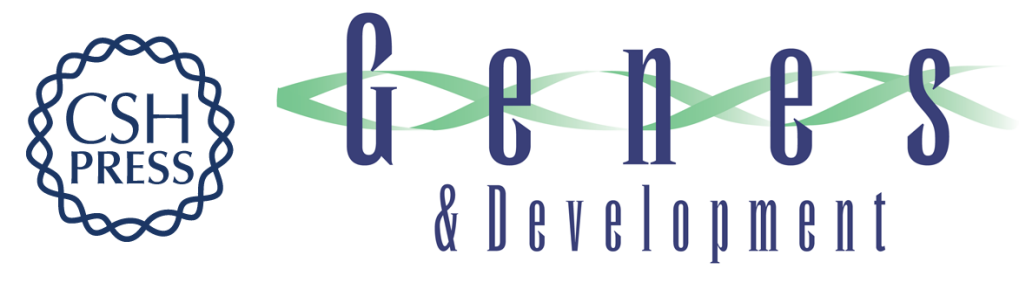

\section{Time to move the fat}

Benjamin P. Weaver, Aileen K. Sewell and Min Han

Genes Dev. 2016, 30:

Access the most recent version at doi:10.1101/gad.285460.116

Related Content A microRNA program in the C. elegans hypodermis couples to intestinal mTORC2/PQM-1 signaling to modulate fat transport Robert H. Dowen, Peter C. Breen, Thomas Tullius, et al. Genes Dev. July, 2016 30: 1515-1528

References This article cites 12 articles, 1 of which can be accessed free at: http://genesdev.cshlp.org/content/30/13/1481.full.html\#ref-list-1

Articles cited in:

http://genesdev.cshlp.org/content/30/13/1481.full.html\#related-urls

Creative This article is distributed exclusively by Cold Spring Harbor Laboratory Press for the first Commons License six months after the full-issue publication date (see http://genesdev.cshlp.org/site/misc/terms.xhtml). After six months, it is available under a Creative Commons License (Attribution-NonCommercial 4.0 International), as described at http://creativecommons.org/licenses/by-nc/4.0/.

Email Alerting Receive free email alerts when new articles cite this article - sign up in the box at the top Service right corner of the article or click here.

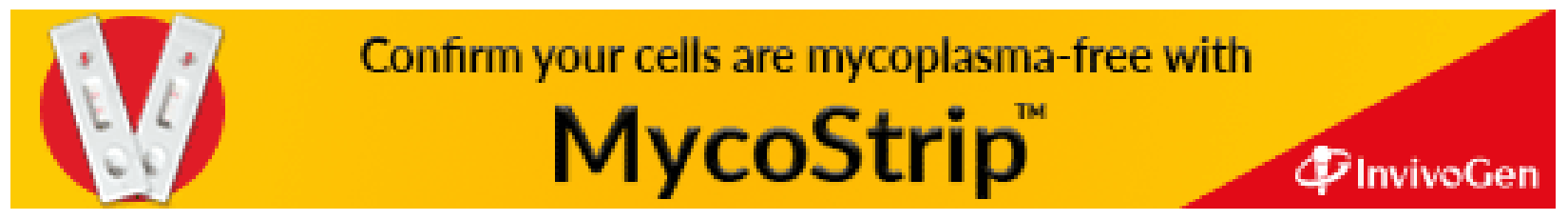

